Seismic Design

Requirements Selection

Methodology for the

Sludge Treatment and

M-91 Solid Waste

Processing Facilities

Projects

Prepared for the U.S. Department of Energy

Assistant Secretary for Environmental Management

Project Hanford Management Contractor for the

U.S. Department of Energy under Contract DE-AC06-96RL13200

FLUOR。

P.O. Box 1000

Richland, Washington

Anproved for Public Release;

Further Dissemination Untimited 


\section{Seismic Design Requirements Selection Methodology for the Sludge Treatment and M-91 Solid Waste Processing Facilities Projects}

\section{G. W. Ryan}

Fluor Hanford, Inc.

Date Published

April 2008

Prepared for the U.S. Department of Energy

Assistant Secretary for Environmental Management

Project Hanford Management Contractor for the

U.S. Department of Energy under Contract DE-AC06-96RL13200

\section{FLUOR.}

\section{P.O. Box 1000}

Richland, Washington
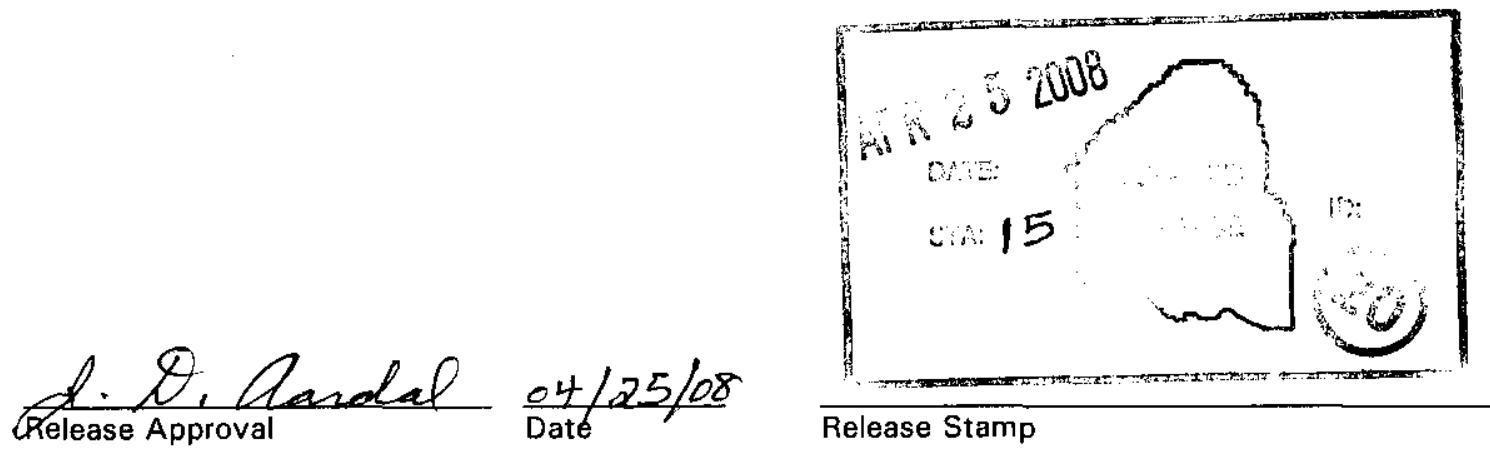

Release Stamp

\section{Approved for Public Release: \\ Further Dissemination Untimited}


HNF-36364

Revision 0

TRADEMARK DISCLAIMER

Reference herein to any specific commercial product, process,

or service by trade name, trademark, manufacturer, or

otherwise, does not necessarily constitute or imply its

endorsement, recommendation, or favoring by the United

States Government or any agency thereof or its contractors or subcontractors.

This report has been reproduced from the best available copy

Printed in the United States of America

Total Pages: 14 
HNF-36364 REV 0

This page left blank. 


\section{CONTENTS}

$1.0 \quad$ PURPOSE AND SCOPE

2.0 OVERVIEW OF SEISMIC DESIGN REQUIREMENTS METHODOLOGY .................. 1

3.0 DESCRIPTION OF SEISMIC METHODOLOGY ELEMENTS AND

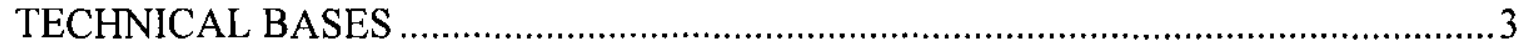

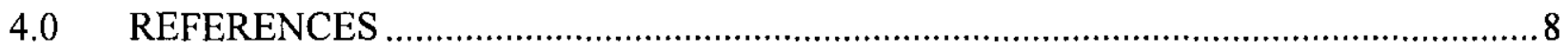

\section{FIGURES}

Figure 1. Seismic Design Requirements Selection Methodology.

\section{TABLES}

Table 1. Description of Seismic Methodology Elements and Technical Bases ............................. 3 
HNF-36364 REV 0

\section{TERMS}

$\mathrm{CD}$

DOE

FH

IBC

M-91 Project

PC

PHMC

RL

SDC

SSC

STP
Critical Decision

U.S. Department of Energy

Fluor Hanford, Inc.

International Building Code

M-91 Solid Waste Processing Facilities Project

Performance Category

Project Hanford Management Contract

U.S. Department of Energy, Richland Operations Office

Seismic Design Category

Structure, System, and Component

Sludge Treatment Project 


\subsection{PURPOSE AND SCOPE}

In complying with direction from the U.S. Department of Energy (DOE), Richland Operations Office (RL) (07-KBC-0055, "Direction Associated with Implementation of DOE-STD-1189 for the Sludge Treatment Project," and 08-SED-0063, "RL Action on the Safety Design Strategy (SDS) for Obtaining Additional Solid Waste Processing Capabilities (M-91 Project) and Use of Draft DOE-STD-1189-YR"), it has been determined that the seismic design requirements currently in the Project Hanford Management Contract (PHMC) will be modified by DOE-STD-1189, Integration of Safety into the Design Process (March 2007 draft), for these two key PHMC projects. Seismic design requirements for other PHMC facilities and projects will remain unchanged.

Considering the current early Critical Decision (CD) phases of both the Sludge Treatment Project (STP) and the Solid Waste Processing Facilities (M-91) Project and a strong intent to avoid potentially costly re-work of both engineering and nuclear safety analyses, this document describes how Fluor Hanford, Inc. $(\mathrm{FH})$ will maintain compliance with the PHMC by considering both the current seismic standards referenced by DOE O 420.1B, Facility Safety, and draft DOE-STD-1 189 (i.e., ASCE/SEI 43-05, Seismic Design Criteria for Structures, Systems, and Components in Nuclear Facilities, and ANSI/ANS 2.26-2004, Categorization of Nuclear Facility Structures, Systems and Components for Seismic Design, as modified by draft DOESTD-1189) to choose the criteria that will result in the most conservative seismic design categorization and engineering design.

Following the process described in this document will result in a conservative seismic design categorization and design products. This approach is expected to resolve discrepancies between the existing and new requirements and reduce the risk that project designs and analyses will require revision when the draft DOE-STD-1189 is finalized.

It is recognized that this methodology may require updating upon approval and issuance of DOE-STD-1189.

\subsection{OVERVIEW OF SEISMIC DESIGN REQUIREMENTS METHODOLOGY}

Figure 1 is a graphical depiction of the methodology that has been developed to identify the design requirements that will be applied to the design of the STP and M-91 Project. 
Figure 1. Seismic Design Requirements Selection Methodology.

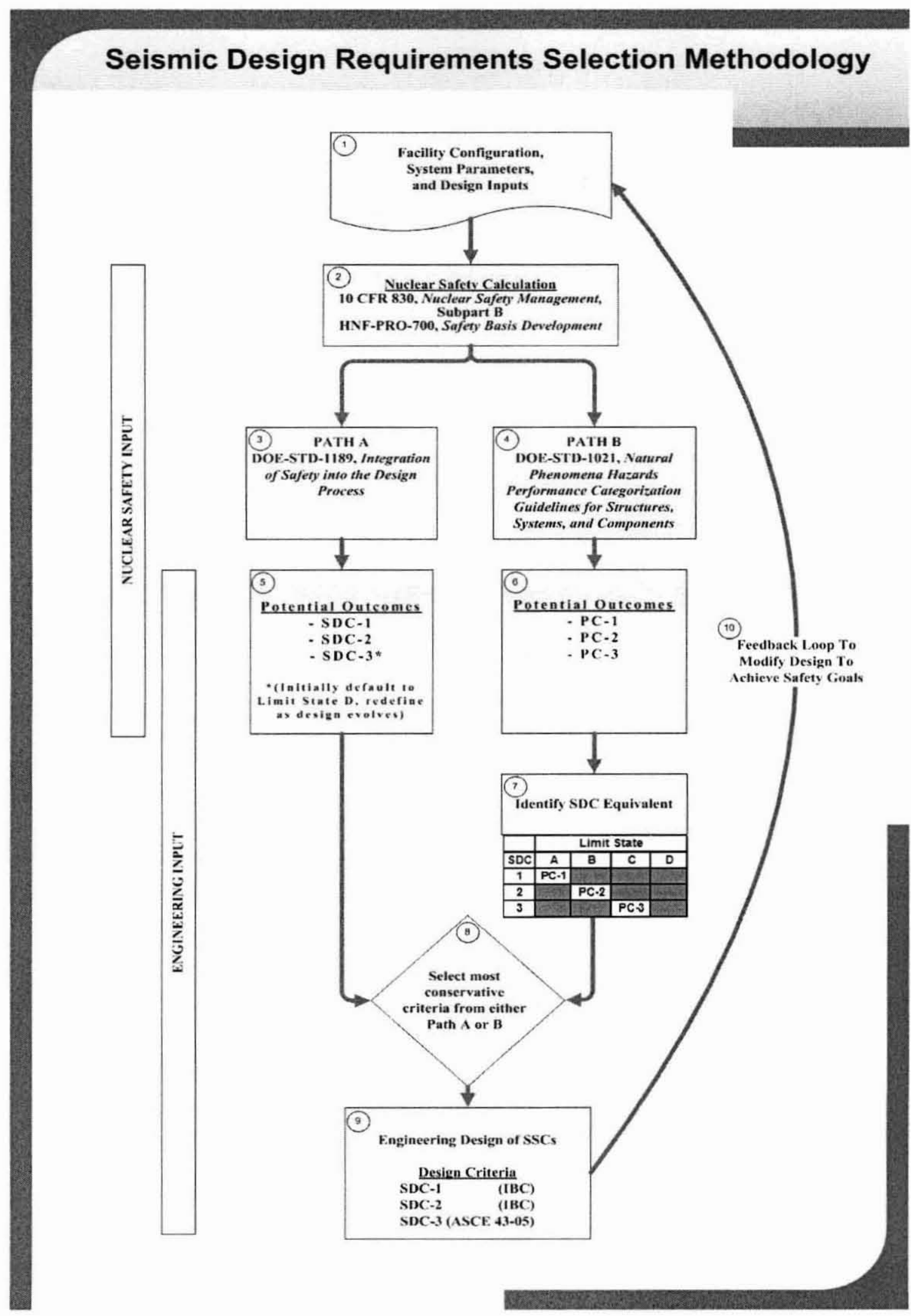




\subsection{DESCRIPTION OF SEISMIC METHODOLOGY ELEMENTS AND TECHNICAL BASES}

This section includes, in tabular form, a detailed description of the technical bases and related information for each of the flow chart blocks included in Figure 1.

Table 1. Description of Seismic Methodology Elements and Technical Bases. (5 sheets)

\begin{tabular}{|c|c|}
\hline Seismic Methodology Element & Technical Bases \\
\hline 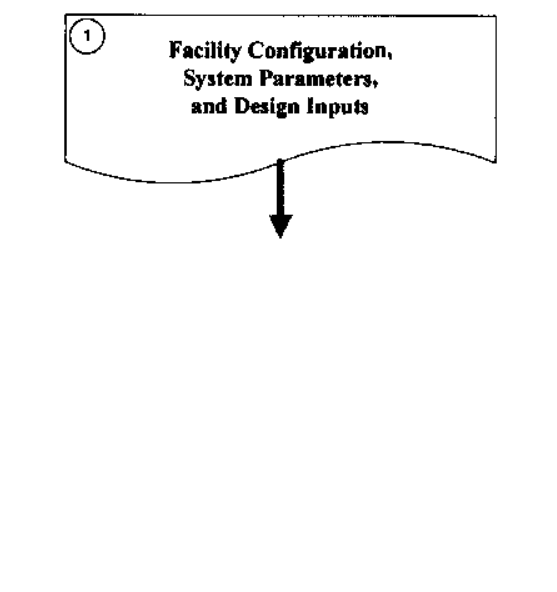 & $\begin{array}{l}\text { In accordance with HNF-8739, Hanford Safety Analysis and } \\
\text { Risk Assessment Handbook (SARAH) }{ }^{1} \text {, hazard and accident } \\
\text { analysis is based on a review of existing and available } \\
\text { documentation. For the facility in design, DOE-STD-1 } 189 \\
\text { defines the requisite documentation as: facility general layout } \\
\text { drawings; process and instrumentation diagrams; process flow } \\
\text { sheets; electrical one-line diagrams; and a listing of material at } \\
\text { risk by location. Additional information that may be required } \\
\text { to define energy sources includes such items as equipment } \\
\text { elevations; tank and piping pressure ratings; pump curves; and } \\
\text { process temperatures and pressures. } \\
\text { This element is a direct feed into Block } 2 \text {. }\end{array}$ \\
\hline $\begin{array}{l}\text { (2) Nuclear Safety Calculation } \\
10 \text { CFR 830, Nuclear Safety Management, } \\
\text { SNF-PRO-700, Subperty Basis Development }\end{array}$ & $\begin{array}{l}\text { Scenario development and consequence calculations are } \\
\text { performed in accordance with DOE-STD-3009, Preparation } \\
\text { Guide for U.S. Department of Energy Nonreactor Nuclear } \\
\text { Facility Safety Analysis, which provides a safe harbor } \\
\text { methodology under 10 CFR 830, Nuclear Safety Management, } \\
\text { Subpart B, "Safety Basis." The specific methodology agreed } \\
\text { upon by RL and FH for PHMC work is documented in } \\
\text { HNF-PRO-700, "Safety Basis Development," and HNF-8739. } \\
\text { Candidate engineered controls are classified as Safety Class or } \\
\text { Safety Significant based on the criteria contained in HNF-8739. } \\
\text { This element is a direct feed into Blocks } 3 \text { and } 4 \text {. }\end{array}$ \\
\hline
\end{tabular}

${ }^{1}$ HNF-8739, Hanford Safety Analysis and Risk Assessment Handbook (SARAH), is the RL-approved PHMC methodology for hazard and accident analysis. 
HNF-36364 REV 0

Table 1. Description of Seismic Methodology Elements and Technical Bases. (5 sheets)

\begin{tabular}{|c|c|}
\hline Seismic Methodology Element & \multicolumn{1}{|c|}{ Technical Bases } \\
\hline $\begin{array}{c}\text { PATH A } \\
\text { DOE-STD-1189, Integration } \\
\text { of Safety into the Design } \\
\text { Process }\end{array}$ & $\begin{array}{l}\text { The consequence calculation performed in Block 2 is modified } \\
\text { as mandated by DOE-STD-1189, Appendix A, which specifies } \\
\text { an alternate dispersion coefficient for the collocated worker. } \\
\text { This element is a direct feed into Block 5. }\end{array}$ \\
\hline $\begin{array}{c}\text { PATH B } \\
\text { DoE-STD-1021, Natural } \\
\text { Phenomena Hazards } \\
\text { Performance Categorization } \\
\text { Guidelines for Structures, }\end{array}$ & \begin{tabular}{l} 
Consequence calculations performed for use with \\
DOE-STD-1021, Natural Phenomena Hazards Performance \\
Categorization Guidelines for Structures, Systems, and \\
Components, are required to be performed and safety \\
classification(s) assigned to candidate engineered controls in \\
accordance with DOE-STD-3009. Additional structures, \\
systems, and components (SSC) may be assigned a safety \\
classification as prescribed in DOE-STD-1021 based on such \\
considerations as common-cause failure or adverse affect on \\
operator actions. \\
\hline
\end{tabular} \\
\hline \begin{tabular}{l} 
This element is a direct feed into Block 6. \\
\hline
\end{tabular}
\end{tabular}




\section{HNF-36364 REV 0}

Table 1. Description of Seismic Methodology Elements and Technical Bases. (5 sheets)

\begin{tabular}{|c|c|}
\hline Seismic Methodology Element & Technical Bases \\
\hline $\begin{array}{l}\text { Potential Outcomes } \\
\text { - SDC-1 } \\
\text { - SDC-2 } \\
\text { - SDC-3* } \\
\\
\text { "(Initially default to } \\
\text { Limit State D, redefine } \\
\text { as design evolves) } \\
\end{array}$ & $\begin{array}{l}\text { Results of the consequence calculation performed in Block } 2 \text {, } \\
\text { as modified in Block } 3 \text {, are compared with the criteria provided } \\
\text { in ANSI/ANS } 2.26 \text {, as modified by Appendix A of } \\
\text { DOE-STD-1189, to make a determination of the SSC Seismic } \\
\text { Design Category (SDC). } \\
\text { The block at left shows that for a potential outcome of SDC-3, } \\
\text { the direction is to initially default to Limit State } D^{2} \text {. This } \\
\text { decision is expected to be refined as the design evolves and } \\
\text { additional information is gained. } \\
\text { If sufficient information on SSC safety function is available to } \\
\text { justify a Limit State of less than Limit State D, that justification } \\
\text { will be prepared and the Limit State will be downgraded } \\
\text { accordingly. } \\
\text { This element is a direct feed into Block } 8 \text {. }\end{array}$ \\
\hline $\begin{array}{l}\text { (6) } \\
\text { Potential Outcomes } \\
\text { - PC-1 } \\
\text { - PC-2 } \\
\text { - PC-3 }\end{array}$ & $\begin{array}{l}\text { Results of the assignment of safety classification performed in } \\
\text { Blocks } 2 \text { and } 4 \text { are compared with the criteria provided in } \\
\text { DOE-STD-1021 to make a determination of the SSC } \\
\text { Performance Category (PC). } \\
\text { This element is a direct feed into Block } 7 \text {. }\end{array}$ \\
\hline
\end{tabular}

${ }^{2}$ Based on the following statement from ANSI/ANS 2.26-2004, Section 4.2.3, no limit state definitions are required for outcomes that result in SDC-1 or SDC-2 determinations: No Limit State identification is required for SDC-1 $s$ and $S D C-2$, whose design requirements are identified in the $I B C$. 
Table 1. Description of Seismic Methodology Elements and Technical Bases. (5 sheets)

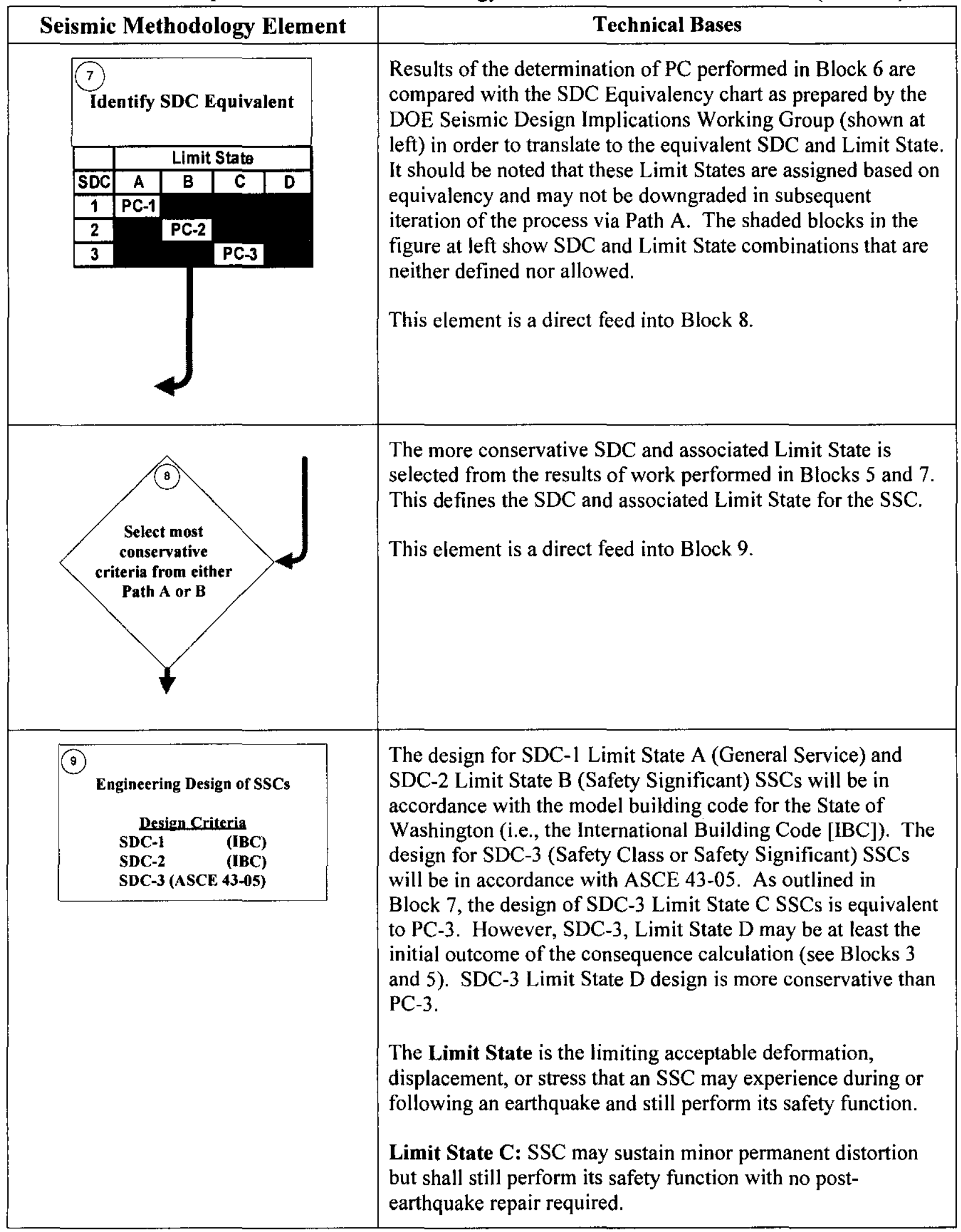


Table 1. Description of Seismic Methodology Elements and Technical Bases. (5 sheets)

\begin{tabular}{|c|c|}
\hline Seismic Methodology Element & Technical Bases \\
\hline & $\begin{array}{l}\text { Limit State D: SSC shall maintain its elastic behavior and } \\
\text { perform its safety function during and following an earthquake. } \\
\text { Gaseous, particulate, and liquid confinement by SSCs is } \\
\text { maintained. } \\
\text { For more details on the Limit States, refer to } \\
\text { ANSI/ANS-2.26-2004. } \\
\text { This block either leads to detailed engineering seismic design } \\
\text { calculations or to the feedback loop described in Item } 10 \text {. }\end{array}$ \\
\hline Feedback Loop (Item 10) & $\begin{array}{l}\text { Item } 10 \text { is included to show a feedback loop to Block } 1 \text {. } \\
\text { The product of Block } 9 \text { becomes the input that is fed back into } \\
\text { Block } 1 \text { and is intended to show the iterative nature of the } \\
\text { design process considering the results of nuclear safety } \\
\text { analysis. Based on design or safety goals that may be } \\
\text { established specific to the project, this loop may be exercised } \\
\text { more than once during each critical decision design phase. } \\
\text { If the results of Block } 9 \text { would have the affect of driving } \\
\text { significant upgrades to existing facilities with limited } \\
\text { remaining life or would substantially increase project } \\
\text { lifecycle costs for limited risk reduction, project personnel } \\
\text { should enter into discussions with their DOE counterparts } \\
\text { to ensure that appropriate decisions are made. }\end{array}$ \\
\hline $\begin{array}{l}\mathrm{PC}=\text { Performance category. } \\
\text { SDC }=\text { Seismic Design Category } \\
\text { SSC }=\text { Structure, system, and component }\end{array}$ & \\
\hline
\end{tabular}


HNF-36364 REV 0

\subsection{REFERENCES}

10 CFR 830, Nuclear Safety Management, Subpart B, "Safety Basis."

ANSI/ANS 2.26-2004, Categorization of Nuclear Facility Structures, Systems and Components for Seismic Design, American Nuclear Society, La Grange Park, Illinois.

ASCE/SEI 43-05, Seismic Design Criteria for Structures, Systems, and Components in Nuclear Facilities, American Society of Civil Engineers, Reston, Virginia.

DOE O 420.1B, Facility Safety, U.S. Department of Energy, Washington, D.C.

DOE-STD-1021, Natural Phenomena Hazards Performance Categorization Guidelines for Structures, Systems, and Components, U.S. Department of Energy, Washington, D.C.

DOE-STD-1 189, DRAFT, Integration of Safety into the Design Process, U.S. Department of Energy, Washington, D.C., March 2007.

DOE-STD-3009, Preparation Guide for U.S. Department of Energy Nonreactor Nuclear Facility Safety Analysis, Change Notice 3, U.S. Department of Energy, Washington, D.C.

HNF-8739, 2004, Hanford Safety Analysis and Risk Assessment Handbook (SARAH), Rev. 1, Fluor Hanford, Inc., Richland, Washington.

HNF-PRO-700, Safety Basis Development, Fluor Hanford, Inc., Richland, Washington.

07-KBC-0055, 2007, "Direction Associated with Implementation of DOE-STD-1189 for the Sludge Treatment Project," (Letter to C. M. Murphy, Fluor Hanford, Inc.) S. A. Sieracki, U.S. Department of Energy, Richland Operations Office, September 4.

08-SED-0063, 2008, "RL Action on the Safety Design Strategy (SDS) for Obtaining Additional Solid Waste Processing Capabilities (M-91 Project) and Use of Draft DOE-STD-1189YR," (letter, to C.M. Murphy, Fluor Hanford, Inc.) S. A. Sieracki, and D. S. Shoop, U.S. Department of Energy, Richland Operations Office, January 17. 